\title{
MJN RELATIONSHIP BETWEEN STRESS LEVEL AND ACADEMIC PROCRASTINATION AMONG NEW NURSING STUDENTS
}

\author{
Rizki Muliani*, Haerul Imam, Egi Dendiawan \\ Bhakti Kencana University, Indonesia \\ *Corresponding Authors's Email: rizki.muliani@bku.ac.id
}

\begin{abstract}
Student in the university will undergo complex transition process from high school student life to be university student. They must adapt with academic challenges that should be confronted during study such as assignments, time management, and academic evaluation. This causes students to get stress that lead them to postpone assignments which is called academic procrastination. This study aims to identify relationship between stress level and academic procrastination among new nursing students. Correlational cross-sectional design was applied in this study in which 145 students were selected as sample by total technique sampling. Data collection used academic procrastination scale (APS) and student-life stress inventory (SSI) questionnaire that was analyzed by spearmen rank test. Result show most of student had moderate stress at $82.5 \%$ and moderate academic procrastination at $81.4 \%$. There was significant relationship with medium magnitude between level of stress and academic procrastination by spearmen rank test with $p$-value $=0.000$ and $r s=0.442$. Overall, university will be able to help student by guiding and giving motivation in order to reduce burden of freshers during study.
\end{abstract}

Keywords: Level of stress, Academic Procrastination, University Student

\section{INTRODUCTION}

Freshers will undergo process of alteration from high school student life to university student's life. When they are in school, one of the predominant transitition that they should pass is adaptation of the campus life because they are unfamiliar with it (Gan, Hu \& Zhang, 2010). They are expected to possess ability in accomplishing assignments such as studying optimally as well as should be able to well manage their time. Indisciplined freshers' students will face obstacles related to time management in completing their assignments. As a result, many tasks will be delayed both in case of learning and assigments completion. Indiscipline and delayed behavior in doing task is called academic procrastination (Mujiyati, 2015).

Academic procrastination is tendencies to procrastinate activities related to studying in academic field (McCloskey, 2011). Ellis and Knaus show around 95\% student in US delayed start or completion of the assigments in delibrated way and more than other $70 \%$ students did it repeatedly (Sepehrian \& Lotf, 2011). In Indonesia, majority students at around $75 \%$ has procrastination in which high procrastination dominate the procatination score at around $30 \%$ than other levels (Surijah \& Tjundjing, 2007). Students with worst case of procrastination, did not complete the assignments till the deadline of submitting, unprepared test such not studying in a manner to get bad score which lead them to not pass the course and get low grade point average (GPA). All these made them to take longer time to finish their study than others (Surijah \& Tjundjing, 2007; Ferrari, 2010).

Stress contribute on procrastination among $14.1 \%$ of the students (Handayani \& Abdullah, 2016). Also, one of the syndromes arise due to procrastinator is caused due to stress (Ghufron \& Risnawita, 2014). The common stress experienced by students is academic stress that is described as condition in which academic tasks are beyond their capability accompanied by any physical, emotional, cognitive changes and some behavioral reactions that lead them to face those condition (Gadzella \& Masten, 2005). It seems that stress on freshers higher than others (Augesti et al., 2015). As a fresher, they need adapt and learn many subjects in a short time which sometimes put them on 
imperfect condition to study (Fiedlander, 2007). Other studies described that freshers tend to have high stress as they must adapt with many lectures (Elias, Ping \& Abdullah, 2011).

Students will get problem physically and psychologically when they could not tackle their stress. Physically, they will get headache and digestive system problem whereas they will suffer many difficulties such as cognitive, emotion, and behavior problem in term of psychology. These influence them psychologically and pose negative effect on memory, sadness, and procatination (Sarafino \& Smith, 2011).

\section{METHODOLOGY}

This study uses cross sectional corelative study. The population is all new students of Bhakti Kencana Health Science School as many as 145 students and total sampling technique was used to get the sampel. Acording to instrument, researchers used Student-Life Stress Inventory (SSI) from Gadzella \& Masten to investigate the student stress whereas Academic Procrastination Scale (APS) was developed by McCloskey to measure procastination. Data was analyzed by Spearman Rank.

\section{RESULTS AND DISCUSSION}

Based on the table 1 it is shown that majority of the new nursing students $(82.5 \%)$ has moderate stress level. This poses enough risk because this situation will remain for hours to some days causing conflict and incomplete assignments and poor performance. Moderate and high level of stress could obstacle learning process (Potter \& Perry, 2005) and lot of demands and tasks are causes of stress on the new nursing students (Olejnik \& Holschuh, 2007). Student stressor include time management, academic demands, and academic envirounment such as assignments, decreasing motivation, descrease role of academics, and hectic and unclear schedule (Agolla \& Ongori, 2009).

\section{Table 1: Stress Level Frequency Distribution}

\begin{tabular}{|l|c|c|}
\hline Stress Level & Frequency & \% \\
\hline Mild & 17 & 11.7 \\
\hline Moderate & 120 & 82.5 \\
\hline Severe & 8 & 5.5 \\
\hline Total & 145 & 100 \\
\hline
\end{tabular}

Result showed that the biggest stressor is affected by pressure like burden or demands that have profound effect. High demands lead freshers to feel the pressure during their study period. They are put to various demands in the same time. This situation has been supported by previous study that academic pressure will affect in the increase of stress among students during studying process (Krumrei et al., 2013; Mahmoud, 2012).

In line with this statement, another study (Rakhmawati, Farida \& Nurhalimah, 2014) stated that high demand of university academic, long duration of lecture, and pressure many assignments within short time, mid and final test report and parental demand make nursing students exhasuted. Beside their hectic schedule, they should also complete their assignments, find literature review and textbook. These statements are in line with other studies that show lack of textbook or journal in universities. The nursing students also become exhausted due to stres. Also, Gadzella \& Masten (2005) mentioned similar opinion whereas exhaustion is one of the most frequently experienced physiologic stress among the nursing students.

Complex transition of freshers from high school students to become university student could pose stress on them. As they are not efficient enough to study long hours and are not aware of the technique to face hard courses (Fiedlander, 2007). In line with this, previous study shows that this change in process of academic causes stress on the students. Then, stress have psychological effects which have some negative feedback such as depletion of memory, anxiety, sadness, and procrastination (Sarafino \& Smith, 2011). Regarding psycologic impact, students experienced fear, anxiety, and worry about their academic demands. They worried regarding test, so it is the biggest stressor for them.

For the student to feel relieved, they need some activities to manage their stress. Nasir \& Muhith (2011) said that basic principle of stress management is to identfy the causes of stress by understanding the causes and level of stress and the reaction towards it. Proper time management will create new environment to be able to reduce impact of stress. They must share and express feeling with trusted person, writing dairy as visualization and mental comparison is the well-known technique to release stress. Other tehniques are relaxation deep breathing regularly, yoga, and meditation.

Good time management provide a person with enough time for many activities, so it can decrease their stress. This statement has been supported by interview 
result with student affair of nursing major which said students felt stress during lecture and are unable to manage time to complete their work. Nonetheless, it is not supported by real data (Hawari, 2011).

University has created programs such as giving teachers for consultation and class advisor, attending some organization and ESQ (Emotional Spiritual Quotients) training. But each program has an obastacle that force it not to run properly. First, comparison between academic advisor and students shows imbalance. So, the consultation time for the students is not enough. Secondly, as a result of hectic schedule of lecture they are unable join any organizations. Third, ESQ training could not be held during that time due to some problem.

Based on the table 2, it seems that majoritynew nursing students $(81.4 \%)$ has moderate academic procrastination. It means they have risk to procrastinate even though they did not make it a habit. Signs of procrastination at this level are delay in start and completion of their assignments, delay in submitting their work, and discrepancy in time in planning and excecution, and fail to choose others fun activities (Ferrari, 2010).

\section{Table 2: Academic Procrastination Frequency Distribution}

\begin{tabular}{|l|c|c|}
\hline Academic Procrastination & Frequency & \% \\
\hline Low & 23 & 15.9 \\
\hline Moderate & 118 & 81.4 \\
\hline High & 4 & 2.8 \\
\hline Total & 145 & 100 \\
\hline
\end{tabular}

Previous study shows similar result that stated more than half students around $54.5 \%$ has moderate procrastination (Melisa \& Astrini, 2012). Students who has bad time management will face many obstacles related to finishing their assigments and delaying their work (Mujiyati, 2015). Another study said that time management is the biggest factor that influenced their procrastination in moderate level. This problem occurs among students from basic school till university level that shows its effects on the submitting of their assigments and the time that they go to school (Puswati, 2014).

There are other studies that said that procastination is one of behavior that lead to inefficient time management and these students tend not to complete the assignments on time (Ghufron \& Risnawita, 2014). Students were expected to have competency to complete their task such as studying opmtimally.
Regarding to their problem related to study and completing the task, they will show renunciation (Kandemir, 2014). Hence, procrastination is a bad behavior as result of which student waste time with poor work performance (Beheshtifar \& Nasab, 2012). Moreover, this study shows laziness associate with academic procastiation. When they were given assignments, they will delay it even they will not complete it till the deadline. When they face exam, they will study only on the night before exam. There are similar studies with comparable results (Ferrari, 2010).

Related to moderate level of academic procrastination, students will waste their time for unimportant things, delay the actual task, and feel disturbed by their friends which make them unfocus. It is supported by theory (McCloskey, 2011) that said procrastinator tend sleep more, watch $\mathrm{TV}$, and play around with their friends in order to avoid and distract from their responsibility.

In this study, moreover, students admitted to university are unable to concentrate and study one night before the exam day. It has been described by theory that academic procrastination aspect is study for exam. For example, they delay to study before exam. They felt one-night study before the day of exam is the best method. Academic procrastination gives negative impact on new nursing students such as wasting time with unimportant things, increasing burden of mind, easily get pressurised, lack of confidence, anxiety, and unable to complete their assignments (Ferrari \& Morales, 2014). Therefor, it needs tangible program to tackle procrastination among new nursing students. Some journals said behaviouristic group conseling are a way to reduce academic procrastination. Conseling could be performed by learning new behavior such as completing work on time, having good time management, discipline, and eliminating maladaptive behavior, strengthening their desire, and giving fun reinforcement after having good behavior immediately (Puswati, 2014).

Based on the Tabel 3, it shows rs score is 0.442 more than $\mathrm{r}$ score $0 / 162$ and $p$-value at around $0.000<\alpha$ score at 0.05 . This result means level of stress associate with academic procrastination on new nursing students of nursing major of Bhakti Kencana Health Science School. It means stress influence students and make their psychologically negative such as decrease of memory, increased anxiety, sadness, and procrastination of their work (Sarafino \& Smith, 2011). 
Table 3: Relationship between stress level and academic procrastination among new nursing students

\begin{tabular}{|c|c|c|c|c|c|c|c|c|}
\hline \multirow{2}{*}{ Stress Level } & \multicolumn{3}{|c|}{ Academic Procrastination } & \multirow{2}{*}{ Total } & \multirow{2}{*}{$\propto$} & \multirow{2}{*}{$p$-value } & \multirow{2}{*}{$r s$} & \multirow{2}{*}{ r table } \\
\hline & Low & Moderate & High & & & & & \\
\hline Mild & $\begin{array}{c}10 \\
6.9 \%\end{array}$ & $\begin{array}{c}7 \\
4.8 \%\end{array}$ & $\begin{array}{c}0 \\
0 \%\end{array}$ & 17 & \multirow{4}{*}{0.05} & \multirow{4}{*}{0.000} & \multirow{4}{*}{0.442} & \multirow{4}{*}{0.162} \\
\hline Moderate & $\begin{array}{c}13 \\
9 \%\end{array}$ & $\begin{array}{c}105 \\
72.4 \%\end{array}$ & $\begin{array}{c}2 \\
1.4 \%\end{array}$ & 120 & & & & \\
\hline High & $\begin{array}{c}0 \\
0 \%\end{array}$ & $\begin{array}{c}6 \\
4.1 \%\end{array}$ & $\begin{array}{c}2 \\
1.4 \%\end{array}$ & 8 & & & & \\
\hline Total & 23 & 118 & 4 & 145 & & & & \\
\hline
\end{tabular}

Their burden is due to overload even it can make them stressed out and as a result they avoid many works (Handayani, 2016). Previous studies said burden, pressure or academic demands pose major impact on student stress (Mahmoud, 2012). Accordingly academic pressure increase stress among students during lecture.

\section{CONCLUSION}

Based on the result and discussion, all in all, there is relationship between level of stress and academic procrastination on the new nursing students of nursing faculty of Bhakti Kencana Health Science School in Bandung Region.

\section{REFERENCES}

Agolla, J.E. \& Ongori, H. (2009). An Assessment of Academic Stress Among Undergraduate Student. Academic Journal, Educational Research and Review, 4(2), pp 63-67.

Augesti, G., Lisnawati, R., Saputra, O. \& Nisa, K. (2015). Differences in Stress Level Between First Year and Last Year Medical Students in Medical Faculty of Lampung University. Journal Majority, 4(4), pp 50-56.

Beheshtifar, M. \& Nasab, H.H. (2012). Effect Procrastination on Organization-Based Self Estem. Innova Ciencia, 4(1), pp 54-59.

Elias, H., Ping, W.S. \& Abdullah, M.C. (2011). Stress and Academic Achievement Among Undergraduate Students in University Putra Malaysia. Procedia-Social and Behavioral Science, 29, pp 646-655.

Ferrari \& Morales, J.F. (2014). Procrastination and Mental Health Coping: A Brief Report Related to Students. Individual Differences Research, 12(1), pp 8-11.

Ferrari, J.R. (2010). Still Procrastinating: The no Regrets Guide to Getting it Done. New Jersey: John Wiley \& Sons.

Fiedlander, L.J. (2007). Social Support, Self Esteem, and Stress as Predictors of Adjustment to University Among First- Year Undergraduates. Journal of College Student Development, 48(3), pp 259-274.

Gadzella, B.M. \& Masten, W.G. (2005). An Analysis of The Categories in The Student-life Stress Inventory. American Journal of Psychology Research, 1(1), pp 1-10.

Gan, Y., Hu, Y. \& Zhang, Y. (2010). Proactive and Preventive Coping in Adjustment to College. The Psychological Record, 60(4), pp 643-658.

Ghufron, M.N. \& Risnawita, R. (2014). Teori-teori Psikologi. Jogjakarta: Ar-Ruzz Media.

Handayani, S.W.R.I. \& Abdullah, A. (2016). Hubungan Stres Dengan Prokrastinasi Pada Mahasiswa. Universitas Wisnuwardhana Malang. Psikovidya, 20(1), pp 32-39.

Hawari, D. (2011). Manajemen Stres, Cemas \& Depresi. Jakarta: Fakultas Kedokteran Universitas Mulawarman.

Kandemir, M. (2014). Reasons of Academic Procrastination: Self-Regulation, Academic Self-Efficacy, Life Satisfaction and Demographics Variables. Procedia-Social and Behavioral Sciences, 152, pp 188-193. 
Krumrei, E.J., Newton, F.B., Kim, E. \& Wilcox, D. (2013). Psychosocial Factors Predicting First-Year College Student Success. Journal of College Student Development, 54(3), pp 247-266.

Mahmoud, J.S., Staten, R., Hall, L.A. \& Lennie, T.A. (2012). The Relationship among Young Adult College Students' Depression, Anxiety, Stress, Demographics, Life Satisfaction, and Coping Styles. Issues in Mental Health Nursing, 33(3), pp 149-156.

McCloskey, J.D. (2011). Finally, My Thesis on Academic Procrastination. Faculty of the Graduate School, The University of Texas at Arlington, Texas. Retrieved from: https://rc.library.uta.edu/uta-ir/bitstream/handle/10106/ 9538/McCloskey_uta_2502M_11260.pdf?sequence=1\&isAllowed=y

Melisa \& Astrini. (2012). Hubungan Antara Tingkat Stres Dengan Perilaku Prokrastinasi Akademik Pada Mahasiswa Universitas Bina Nusantara Yang Sedang Mengerjakan Skripsi. Skripsi, Program Sarjana Universitas Bina Nusantara, Jakarta.

Mujiyati, M. (2015). Mereduksi Prokrastinasi Akademik Mahasiswa Melalui Teknik Token Economy. Journal Fokus Konseling, 1(2), pp 142-150.

Nasir,A. \& Muhith, A. (2011). Dasar-Dasar Keperawatan Jiwa. Jakarta: Salemba Medika.

Olejnik, S.N. \& Holschuh, J.P. (2007). College Rules! Edition How Study, Survive, and Succeed. New York: Ten Speed Press.

Potter, P.A. \& Perry, A.G. (2005). Fundamental Keperawatan: Konsep, Proses dan Praktik. $4^{\text {th }}$ Edition. Jakarta: EGC.

Puswati (2014). Upaya Mereduksi Prokrastinasi Akademik Melalui Konseling Kelompok Melalui Pendekatan Behavioristik. Psikopedagogia, 3(1), pp 2301-6167.

Rakhmawati, I., Farida, P. \& Nurhalimah. (2014). Sumber Stres Akademik Dan Pengaruhnya Terhadap Tingkat Stres Mahasiswa Keperawatan DKI Jakarta. Journal Keperawatan, 2(3), pp 72-84.

Sarafino, E.P. \& Smith, T.W. (2011). Health Psychology: Biophysical Interactions. Canada: John Wiley \& Sons.

Sepehrian, F. \& Lotf, J.J. (2011). The Effects of Coping Styles and Gender on Academic Procrastination among University Students. Journal of Basic and Applied Scientific Research, 12(1), pp 2987-2993.

Surijah, E.A. \& Tjundjing, S. (2007). Mahasiswa Versus Tugas: Prokrastinasi Akademik Dan Conscientiousness. Anima, Indonesian Psychological Journal, 22(4), pp 352-374. 